\title{
Petrocosmea nanchuanensis (Gesneriaceae), a new species from Chongqing, China
}

\author{
Zhi-Jing Qiu ${ }^{1 *}$, Jun Zhang ${ }^{2,7^{*}}$, Xavier-Ravi Baskaran ${ }^{1,6}$, \\ Jin $\mathrm{Hu}^{3}$, Zhen-Yu Li ${ }^{4}$, Zheng-Yu Liu ${ }^{2,5,7}$
}

I Key Laboratory of Southern Subtropical Plant Diversity, Fairy Lake Botanical Garden, Shenzhen and Chinese Academy of Sciences, Shenzhen, 518004, China 2 Chongqing Institute of Medical Plant Cultivation, Nanchuan, Chongqing, 408435, China 3 Guangdong Eco-Engineering polytechnic, Guangzhou, Guangdong, 510520, China 4 State Key Laboratory of Systematic and Evolutionary Botany, Institute of Botany, Chinese Academy of Sciences, Beijing, 100093, China 5 Resource Center, China Academy of Chinese Medical Sciences, Beijing, 100000, China 6 School of Life Sciences, Sun Yat-sen University, Guangzhou, 510275, China 7 Chongqing Jinfo Mountain Forest Ecosystem Field Scientific Observation and Research Station, Nanchuan, Chongqing, 408435, China

Corresponding author: Zheng-Yu Liu (Liutzy@163.com)

Academic editor: Fang Wen | Received 2 February 2019 | Accepted 11 June 2020 | Published 26 August 2020

Citation: Qiu Z-J, Zhang J, Baskaran X-R, Hu J, Li Z-Y, Liu Z-Y (2020) Petrocosmea nanchuanensis (Gesneriaceae), a new species from Chongqing, China. In: Shui Y-M, Chen W-H, Ren M-X, Wen F, Hong X, Qiu Z-J, Wei Y-G, Kang M (Eds) Taxonomy of Gesneriaceae in China and Vietnam. PhytoKeys 157: 137-144. https://doi.org/10.3897/ phytokeys.157.33625

\begin{abstract}
A new species, Petrocosmea nanchuanensis Z.Y. Liu, Z.Y. Li \& Z.J. Qiu from Mt. Jinfo at Banhe valley of Nanchuan District in Chongqing Municipality (China) is described and illustrated for the first time. Even though this new species is similar to Petrocosmea barbata, it has several significant morphological differences, which includes smaller leaves, repand leaf margin, densely appressed longer pubescences on both surfaces of leaves, larger flower with length of its lower lips about three times longer than that of the upper lips, oblong lower lip lobes, shorter pistil, ovate anthers and styles that are shortly pubescent or approximately glabrous above the middle. The distinct features of $P$. nanchuanensis and four relative species namely, $P$. barbata, $P$. longipedicellata, $P$. cavaleriei and $P$. xanthomaculata were also represented in depth. However, $P$. nanchuanensis is most closely related to $P$. barbata, based on molecular studies.
\end{abstract}

\section{Keywords}

Gesneriaceae, new species, Petrocosmea nanchuanensis

\footnotetext{
* Contributed equally as the first author.
}

Copyright Zhi-ling Qiu et al. This is an open access article distributed under the terms of the Creative Commons Attribution License (CC BY 4.0), which permits unrestricted use, distribution, and reproduction in any medium, provided the original author and source are credited. 


\section{Introduction}

The genus Petrocosmea Oliver, (1887) (Family: Gesneriaceae, Subfamily: Didymocarpoideae, Tribe: Trichosporeae) was established in 1887. At present, Petrocosmea genus consists of 50 species classified into five sections: sect. Petrocosmea Oliv., (1919), sect. Anisochilus Hemsl., (1899), sect. Minor Zhi J. Qiu, (2015), sect. Barbata Zhi J. Qiu, (2015) and sect. Deinanthera W.T. Wang, (1985) (Oliver 1887; Wang 1985; Wang et al. 1990, 1998; Burtt 1998, 2001; Li and Wang 2005; Wei and Wen 2009; Qiu et al. 2011, 2012, 2015). Herein, we report the discovery of a new species present on Mt. Jinfo in the Banhe valley, Nanchuan District, Chongqing Municipality of China. This new species has unconstructed anthers and an abaxial corolla lip that is approximately three times longer than the adaxial one with two yellow spots at the base of the lower lip's lobes. Hence, the new species, P. nanchuanensis belongs to sect. Barbata.

\section{Materials and methods}

Measurements and observations of morphological characters of the new species, based on living individuals and specimens, were carried out in the field or greenhouse and at the herbarium. Hairs and glandular hairs and other tiny morphological characters were observed and measured by using a stereomicroscope (Nikon SMZ18). Morphological comparisons with related species were measured, based on living individuals in the greenhouse and specimens from PE, SZBG and KUN herbaria.

\section{Taxonomy}

Petrocosmea nanchuanensis Z.Y. Liu, Z.Y. Li \& Z.J. Qiu, sp. nov. urn:Isid:ipni.org:names:77211190-1

Figs 1, 2

Diagnosis. Petrocosmea nanchuanensis is morphologically similar to P. barbata Craib, but is distinguished from the latter by smaller leaves, a repand leaf margin, densely appressed longer pubescences on both surfaces of its leaves, larger flower with the length of its lower lips three times longer than that of the upper lips, oblong lower lip lobes, shorter pistil, ovate anthers and styles that are shortly pubescent or approximately glabrous above the middle.

Type. China. Chongqing Municipality: Nanchuan, Banhegou, Mt. Jinfo, 20 Sep 2002. Z. Y. Li 2002016 (holotype, PE).

Description. Perennial herb, rosette-forming, with a short rhizome and crowded fibrous roots. Leaves 8 to 30, all basal, crowded, the inner leaves with short or absent petioles, the outer leaves with longer petioles; leaves orbicular-ovate, broad-ovate, cordate or almost circular, $0.5-2 \times 0.7-2 \mathrm{~cm}$, herbaceous, apex round, base cordate, 


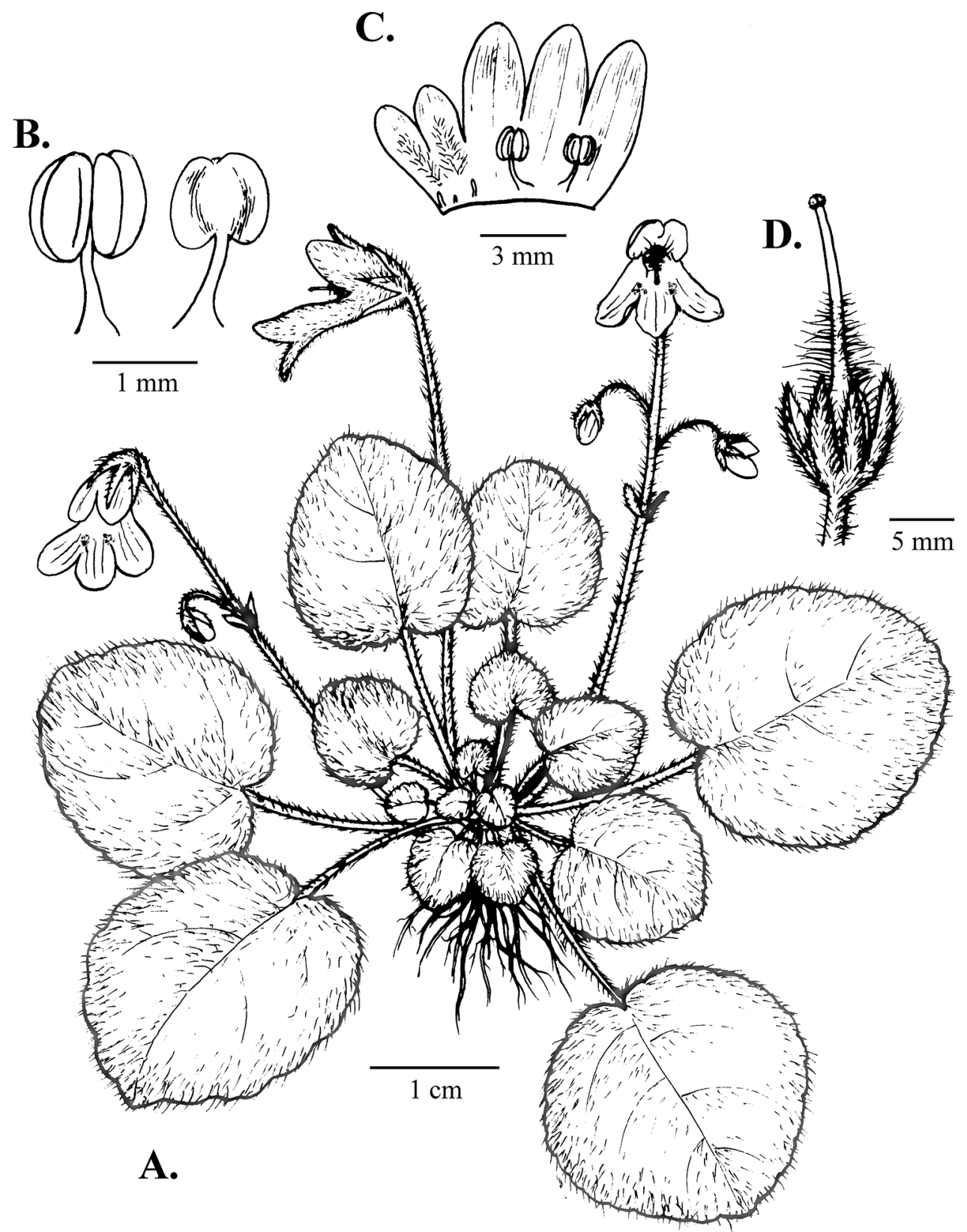

Figure I. Drawing of Petrocosmea nanchuanensis Z.Y. Liu, Z.Y. Li \& Z.J. Qiu, sp. nov. A habit B stamens $\mathbf{C}$ dissected corolla $\mathbf{D}$ calyx and pistil.

margin undulate teeth, both surfaces with densely villous, lateral veins 3 on each side, not distinct; petioles $0.5-6 \mathrm{~cm}$, densely pilose. Cymes 5 to $15,1-3$ flowers per cyme; peduncle 3-10 cm, densely pilose; bracts 2 at upper- or middle-peduncle, lanceo- 

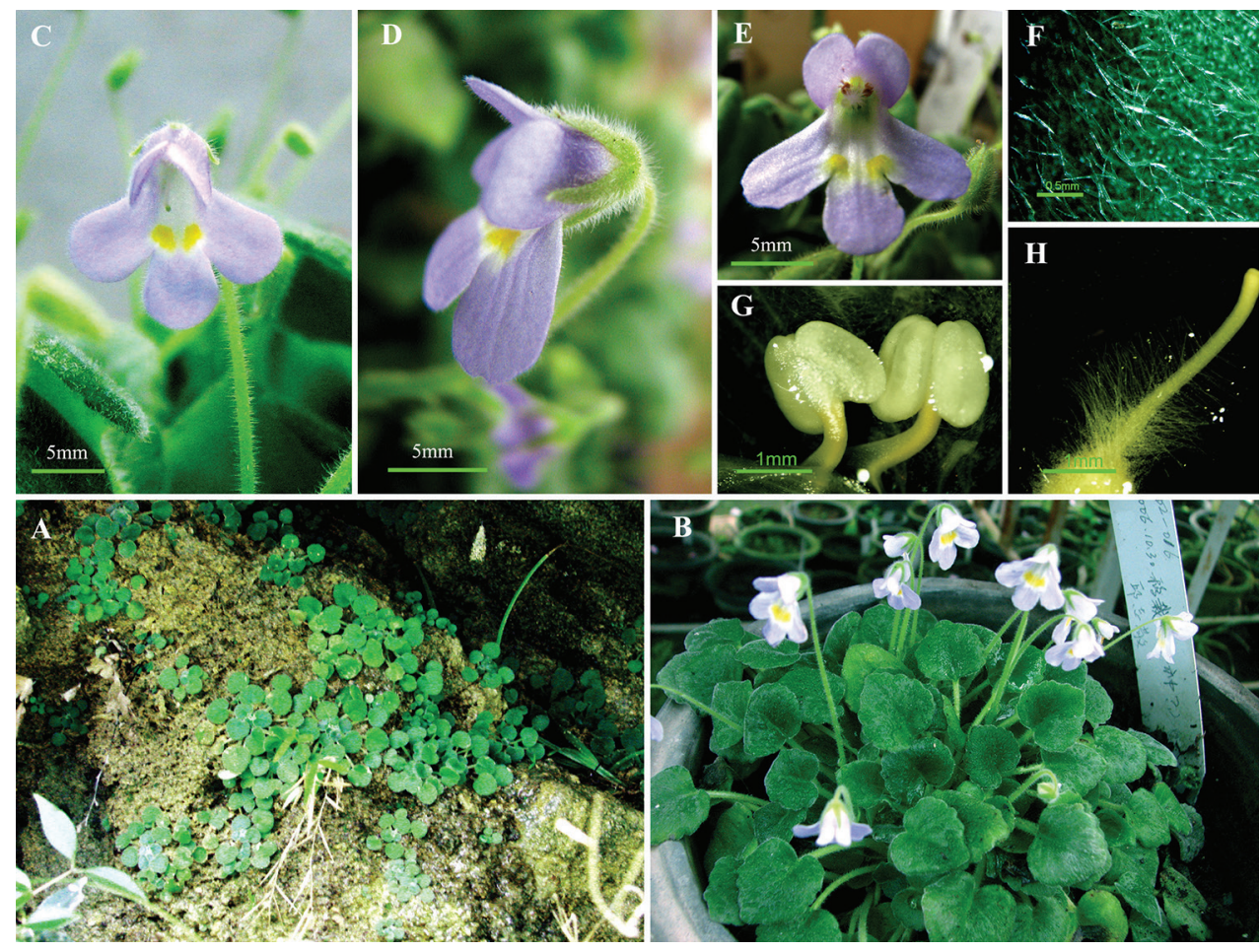

Figure 2. Petrocosmea nanchuanensis Z.Y. Liu, Z.Y. Li \& Z.J. Qiu A habitat B flowering plants $\mathbf{C}$ flower, front view $\mathbf{D}$ flower, side view $\mathbf{E}$ flower, front view, showing pistil and anthers $\mathbf{F}$ hairs on abaxial leaves $\mathbf{G}$ stamens $\mathbf{H}$ hairs on the pistil.

late, $0.5-1.2 \mathrm{~cm}$, pubescent, pedicel $1-5 \mathrm{~cm}$, densely hairy; sepals 5-divided to the base, narrow-lanceolate, ca. $4-5 \mathrm{~mm}$, pubescent externally. Corolla light purple or white, outside and inside abaxial lip puberulent, inside adaxial lip and tube near mouth densely pubescent, 2 yellow spots inside abaxial lip base; tube ca. $3 \mathrm{~mm}$, adaxial lip ca. 3-3.5 mm, bi-lobed near to base, lobes ovate, abaxial lip ca. 8-9 mm, deeply tri-lobed, lobes oblong; stamens 2, ca. $2.2 \mathrm{~mm}$; filaments adnate to ca. $1 \mathrm{~mm}$ above the base of corolla tube, ca. $1.2 \mathrm{~mm}$ long, glabrous; anthers ovate, ca. $1 \mathrm{~mm}$ long, glabrous; staminodes 3 , adnate to ca. $0.2-0.4 \mathrm{~mm}$ above the base of the corolla tube, ca. $0.3-0.8 \mathrm{~mm}$ long, glabrous; pistil ca. $4.5 \mathrm{~mm}$; ovary densely villous, ovoid, oblique abaxially, ca. $1.5 \mathrm{~mm}$ long; style unfolded pilose and glandular hairs under the middle, shortly pubescent or approximately glabrous above the middle, ca. $3 \mathrm{~mm}$ long.

Habitat and distribution. Petrocosmea nanchuanensis grows on moist shady limestone cliffs or along forest edges at an altitude of 600-650 m on the Mt. Jinfo, Banhe valley, Nanchuan District, Chongqing Municipality, which is adjacent to Guizhou Province in south-western China.

International Union for Conservation of Nature (IUCN) Red List Category. The new species is determined to be Critically Endangered (CR A2c) according to the IUCN Red List of Threatened Species Categories and Criteria (IUCN 2001). About 
850 individuals were found in two separate and restricted populations: 300 individuals were found growing in one location with ca. $4 \times 2 \mathrm{~m}^{2}$ and 550 individuals were found at the other location with ca. $8 \times 3 \mathrm{~m}^{2}$. Petrocosmea nanchuanensis is only known from the type locality, i.e. Nanchuan District and their habitat has been threatened and damaged by deforestation and over-exploitation due to native tourism despite its protection in the Mt. Jinfo National Nature Reserve.

Phenology. The new species was collected with flowers during September-November; fruits were not seen.

Additional specimens studied (paratypes). CHINA. Chongqing: Mt. Jinfo, Nanchuan, 3 Sep 2007, R. H. Liang 2007010 (PE), Z. J. Qiu 2011020 , QZJ-20131082 (SZG), S.Z. Zhang 20121077 (SZG), Z. Y. Liu 500119-1582ly, 500119-1595ly (IMC).

\section{Discussion}

In our previous study, molecular phylogenetic analysis of Petrocosmea genus which includes $P$. nanchuanensis has been studied using six chloroplast DNA regions (atpI-atpH, matK, trnH-psbA, rps16 intron, trnL-F and trnT-L) and two nuclear DNA regions (ITS and $P e C Y C 1 D$ ) (Qiu et al. 2015). The molecular phylogenetic study showed that $P$. nanchuanensis rests at the base of a clade containing three other species, $P$. barbata Craib, (1919), P. longipedicellata W.T. Wang, (1985) and P. cavaleriei Levl., (1911), as shown in Fig. 3. In the phylogenetic tree, this clade, which includes four species, $P$. nanchuanensis, P. barbata, P. longipedicellata and P. cavaleriei, has some morphological synapomorphies, such as two yellow spots at the base of the lower lip lobes, densely villous on the ovary, villous inside corolla tube and glabrous filaments. The phylogenetic tree revealed that P. nanchuanensis is most closely related to P. barbata that also belongs to sect. Barbata.

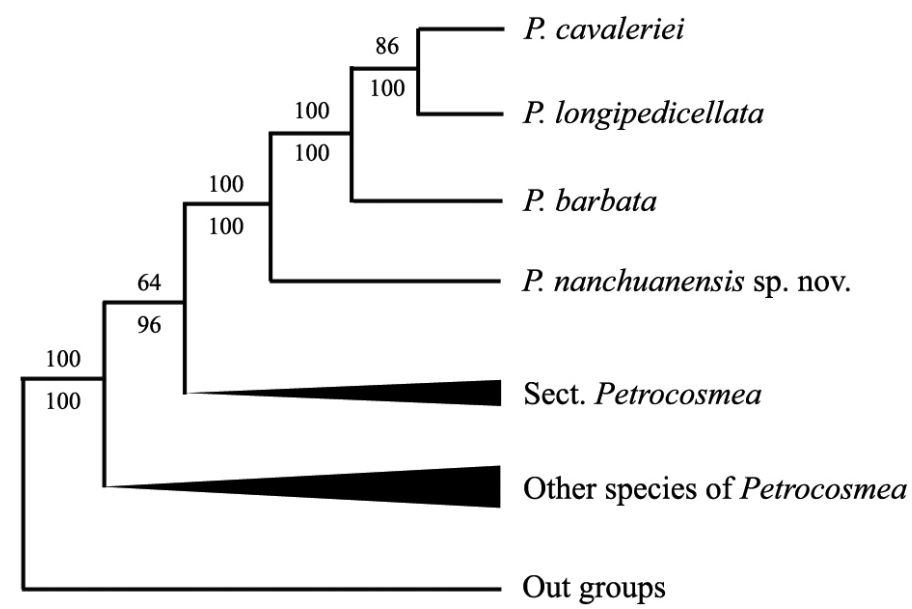

Figure 3. Drawing of the most parsimonious tree generated from six cpDNA and two nrDNA regions (partial \& unpublished). Bootstrap values are shown above branches and Bayesian posterior probabilities are indicated below branches. 
Table I. Distinguishing features of $P$. nanchuanensis in comparison with other related species.

\begin{tabular}{|c|c|c|c|c|c|}
\hline Features & P. nanchuanensis & P. barbata & P. longipedicellata & P. cavaleriei & P. xanthomaculata \\
\hline Leaf shape & Ovate & Round-ovate & Sub circular & Broadly ovate & Broadly ovate \\
\hline $\begin{array}{l}\text { Length of mature } \\
\text { leaves }\end{array}$ & $1.8-2 \mathrm{~mm}$ & $2.5-2.8 \mathrm{~mm}$ & $4-4.5 \mathrm{~mm}$ & $2-2.5 \mathrm{~mm}$ & $2-2.3 \mathrm{~mm}$ \\
\hline Leaf margin & Undulate teeth & Crenate & Shallow-serrate & Repand & Repand \\
\hline Hairs on the leaf & $\begin{array}{l}\text { Densely villous on both } \\
\text { sides }\end{array}$ & $\begin{array}{c}\text { Sparsely appressed } \\
\text { with pubescence above } \\
\text { and slightly densely } \\
\text { pubescent below }\end{array}$ & $\begin{array}{c}\text { Slightly densely } \\
\text { appressed pubescent } \\
\text { on both sides }\end{array}$ & $\begin{array}{l}\text { Pubescent on both } \\
\text { sides }\end{array}$ & Villous on both sides \\
\hline Leaf base & Cordate & Cordate & Truncate & Subcordate & Subcordate \\
\hline $\begin{array}{l}\text { Hairs on the } \\
\text { peduncle and pedicel }\end{array}$ & Unfolded pilose & $\begin{array}{l}\text { Sparsely pubescent } \\
\text { and glandular hairs }\end{array}$ & Unfolded pubescent & $\begin{array}{l}\text { Pubescent and } \\
\text { glandular hairs }\end{array}$ & $\begin{array}{l}\text { Unfolded pilose and } \\
\text { glandular hairs }\end{array}$ \\
\hline Length of corolla & $11-12 \mathrm{~mm}$ & $7-8 \mathrm{~mm}$ & $8-9 \mathrm{~mm}$ & $8-9 \mathrm{~mm}$ & $7-8 \mathrm{~mm}$ \\
\hline $\begin{array}{l}\text { Spots inside the } \\
\text { corolla }\end{array}$ & $\begin{array}{c}\text { There are } 2 \text { yellow spots } \\
\text { at the base of lower } \\
\text { lip lobes }\end{array}$ & $\begin{array}{l}\text { There are } 2 \text { yellow } \\
\text { bands at the base of } \\
\text { lower lip lobes }\end{array}$ & $\begin{array}{l}\text { There are } 2 \text { yellow } \\
\text { spots at the base of } \\
\text { lower lip lobes }\end{array}$ & $\begin{array}{l}\text { There are } 2 \text { yellow } \\
\text { spots at the base of } \\
\text { lower lip lobes and } 3 \\
\text { small yellow spots in } \\
\text { the areas of staminodes }\end{array}$ & $\begin{array}{l}\text { There are } 2 \text { yellow } \\
\text { spots at the base of } \\
\text { lower lip lobes and } 3 \\
\text { small yellow spots in } \\
\text { the areas of staminodes }\end{array}$ \\
\hline $\begin{array}{l}\text { The degree of upper } \\
\text { lip cracking }\end{array}$ & Near base & Near the middle & Near the middle & Near base & Near base \\
\hline $\begin{array}{l}\text { Do the upper lip } \\
\text { lobes press against } \\
\text { each other }\end{array}$ & Yes & No & No & No & Yes \\
\hline $\begin{array}{l}\text { Shape of upper } \\
\text { lip lobe }\end{array}$ & Ovate & Round-ovate & Rounded & Rounded & Rounded \\
\hline $\begin{array}{l}\text { The degree of lower } \\
\text { lip cracking }\end{array}$ & More than the middle & Near the middle & Near the middle & Near base & Near base \\
\hline $\begin{array}{l}\text { Shape of lower lip } \\
\text { lobe }\end{array}$ & Oblong & Broadly ovate & Ovate & Oblong & Long-ovate \\
\hline $\begin{array}{l}\text { The length ratio of } \\
\text { upper to lower lip }\end{array}$ & $-1: 3$ & $-1: 2$ & $-1: 2$ & $-1: 2$ & $-1: 2$ \\
\hline Length of stamen & $2-2.5 \mathrm{~mm}$ & $3-3.5 \mathrm{~mm}$ & $4.5-4.7 \mathrm{~mm}$ & $1.5-1.8 \mathrm{~mm}$ & $1.6-1.8 \mathrm{~mm}$ \\
\hline Shape of anther & Ovate & Round-ovate & Elliptic & Oblate & Round-ovate \\
\hline $\begin{array}{l}\text { Length of lateral } \\
\text { staminodes }\end{array}$ & $0.6-0.8 \mathrm{~mm}$ & $0.2-0.3 \mathrm{~mm}$ & $0.4-0.5 \mathrm{~mm}$ & $0.4-0.5 \mathrm{~mm}$ & $0.4-0.5 \mathrm{~mm}$ \\
\hline Length of pistil & $4.5-5 \mathrm{~mm}$ & $7-8 \mathrm{~mm}$ & $6-7 \mathrm{~mm}$ & $6-7 \mathrm{~mm}$ & $6-7 \mathrm{~mm}$ \\
\hline Hairs on the styles & $\begin{array}{l}\text { Unfolded pilose } \\
\text { and glandular hairs } \\
\text { under the middle, } \\
\text { shortly pubescent or } \\
\text { approximately glabrous } \\
\text { above the middle }\end{array}$ & $\begin{array}{l}\text { Unfolded villous and } \\
\text { short glandular hairs } \\
\text { under the top, short } \\
\text { glandular hairs on } \\
\text { the top }\end{array}$ & $\begin{array}{l}\text { Unfolded pilose } \\
\text { under the top }\end{array}$ & $\begin{array}{c}\text { Unfolded pilose and } \\
\text { glandular hairs under } \\
\text { the middle }\end{array}$ & $\begin{array}{l}\text { Unfolded villous under } \\
\text { the top }\end{array}$ \\
\hline
\end{tabular}

Table 1 summarises the distinguishing features of $P$. nanchuanensis and its related species namely, P. barbata, P. longipedicellata, P. cavaleriei and P. xanthomaculata G.Q. Gou \& X.Y. Wang (2010). Herein, both morphological and our previous molecular studies support $P$. nanchuanensis as a new species and being most similar to $P$. barbata. The foremost morphological differences between $P$. nanchuanensis and $P$. barbata include that $P$. nanchuanensis has smaller leaves than $P$. barbata and $P$. nanchuanensis leaves have an undulate-toothed margin, whereas, P. barbata has a crenate margin. Moreover, $P$. nanchuanensis shows a densely appressed villous on both surfaces of leaves instead of the adaxially puberulent and abaxial slightly and densely puberulent pattern of $P$. barbata.

Likewise, $P$. nanchuanensis has larger flowers than $P$. barbata, in which $P$. nanchuanensis has flowers about three times longer in lower than in upper lips instead of about two times longer in lower than in upper lips in $P$. barbata. Additionally, lower 
lip lobes are oblong in $P$. nanchuanensis instead of broadly ovate in $P$. barbata, while $P$. nanchuanensis has a shorter pistil than $P$. barbata. Besides, $P$. nanchuanensis has styles that are shortly pubescent or approximately glabrous above the middle instead of styles with unfolded villous and short glandular hairs under the top and short glandular hairs on the top in $P$. barbata. The $P$. nanchuanensis has ovate instead of round-ovate anthers in P. barbata.

We conclude that Petrocosmea nanchuanensis belongs to sect. Barbata due to its floral structure, particularly anthers that are not constricted near the apex, the length of its abaxial corolla lip being twice as long as the adaxial and two yellow spots at the base of the lower lips lobes. Even though, this new species is similar to P. barbata and mostly varies through smaller leaves, a repand leaf margin, densely appressed longer pubescences on both surfaces of its leaves, larger flowers with their lower lips about three times longer than the upper lips, oblong lower lip lobes, shorter pistil, ovate anthers and shortly pubescent styles or approximately glabrous above the middle.

Morphological similarity between $P$. nanchuanensis and $P$. barbata has been supported by our previous molecular phylogenetic data (Qiu et al. 2015). A phylogenetic tree, based on six cpDNA regions and two nrDNA regions, confirmed that $P$. nanchuanensis is most closely related to $P$. barbata (Figure 3), which is distributed throughout Kunming County in the east-central portion of Yunnan Province, China.

\section{Acknowledgements}

We are grateful to Ming-Bo Ren (Chongqing Institute of Medical Plant Cultivation) and Rong-Hua Liang (Institute of Botany, Chinese Academy of Sciences) for helping to collect this species. We are also grateful to Yin-Zheng Wang (Institute of Botany, Chinese Academy of Sciences) for useful suggestions during the preparation of this paper. We also thank Ai-Li Li for her excellent drawing of the new species. This work was funded by a Special Research Project of the National Traditional Chinese Medicine Industry, the Fourth National Survey on Chinese Materia Medica Resources, Chongqing (grant 20127002), the National Natural Science Foundation of China (Grant 31200159, 31500187), the Scientific Research Project of Shenzhen Urban Management Bureau $(201705,201807,201926)$ and the Strategic Biological Resources Capacity Building Project of Chinese Academy of Sciences (KFJ-BRP-017-29). We would like to also thank TopEdit (www.topeditsci.com) for its linguistic assistance during the preparation of this manuscript.

\section{References}

Burtt BL (1998) A new species of Petrocosmea. The Gloxinian 1998(1): 14-15.

Burtt BL (2001) Flora of Thailand: Annotated Checklist of Gesneriaceae. Thai Forest Bulletin (Botany) 29: 105-106. 
Craib WG (1919) Revision of Petrocosmea. Not Bot Gard Edinb 11: 269-275.

Gou GQ, Wang XY, Xiong YX (2010) Petrocosmea xanthomaculata G. Q. Gou et X. Y. Wang, a new species of the genus Petrocosmea Oliv. Bulletin of Botanical Research 30(4): 394-396.

IUCN (2001) IUCN Red List Categories and Criteria, Version 3.1. Prepared by the IUCN Species Survival Commission. IUCN, Gland, Switzerland, and Cambridge, United Kingdom.

Li ZY, Wang YZ (2005) Petrocosmea Oliver. Plants of Gesneriaceae in China. Henan Science \& Technology Publishing House, Zhengzhou, 154-166.

Oliver D (1887) Petrocosmea sinensis Oliv. Plate 1716. In: Hooker JD (Ed.) Hooker's Icones Plantarum (Vol. 18). Kew, Bentham-Moxon Trustees.

Qiu ZJ, Liu ZY (2015) Plants of Petrocosmea in China. Science Publishing House, Beijing.

Qiu ZJ, Yuan ZL, Li ZY, Wang YZ (2011) Confirmation of a natural hybrid species in Petrocosmea (Gesneriaceae) based on molecular and morphological evidence. Journal of Systematics and Evolution 49(5): 449-463. https://doi.org/10.1111/j.1759-6831.2011.00151.x

Qiu ZJ, Wang XL, Liu ZY, Yang JF, Zhang SZ (2012) Cytological and phylogenetic study of Petrocosmea hexiensis (Gesneriaceae), a new species from Chongqing, China. Phytotaxa 74(1): 30-38. https://doi.org/10.11646/phytotaxa.74.1.2

Qiu ZJ, Lu YX, Li CQ, Dong Y, Smith JF, Wang YZ (2015) Origin and evolution of Petrocosmea (Gesneriaceae) inferred from both DNA sequence and novel findings in morphology with test of morphology-based hypotheses. BMC Plant Biology 15(1): 1-167. https://doi. org/10.1186/s12870-015-0540-3

Wang WT (1985) The second revision of the genus Petrocosmea. Yunnan Zhi Wu Yan Jiu 7(1): 49-68.

Wang WT, Pan KY, Li ZY (1990) Petrocosmea. In: Wang WT (Ed.) Flora Republicae Popularis Sinicae (Vol. 69). Science Press, Beijing, 329-331.

Wang WT, Pan KY, Li ZY (1998) Petrocosmea. In: Wu ZY, Raven PH (Eds) Flora of China (Vol. 18) (Scrophulariaceae through Gesneriaceae). Science Press, Beijing, and Missouri Botanical Garden Press, St. Louis, 302-308.

Wei YG, Wen F (2009) Petrocosmea xingyiensis (Gesneriaceae), a new species from Guizhou, China. Novon 19(2): 261-262. https://doi.org/10.3417/2007090 